\title{
ANALYSIS OF HELICAL ROLLING PROCESS OF BALLS FORMED FROM A HEAD OF A SCRAPPED RAIL
}

\section{Zbigniew Pater}

\author{
1 Mechanical Engineering Faculty, Lublin University of Technology, Nadbystrzycka 36, 20-618 Lublin, Poland, \\ e-mail: z.pater@pollub.pl
}

Received: 2016.03.06

Accepted: 2016.04.25 Published: 2016.06.01

\begin{abstract}
This paper presents an innovative helical rolling process of balls destined for mills manufactured from a scrapped rail head. In this process, helical rolls are applied, whose construction allows obtaining a cylindrical bar, and later balls are formed from this bar in the further stage of the process. It is advised to precede the rolling process by side pressing leading to increase of billet material shape compactness. Verification of the assumed solution correctness was made using numerical simulation, with the application of Simufact.Forming software.
\end{abstract}

Keywords: helical rolling, balls, FEM.

\section{INTRODUCTION}

Rails are manufactured from cast steel of type R200, R220 and R260 (according to PNEN 13674-1:2006) and they are characterized by good resistance to bending and attrition, hardness and addiotionally, elasticity and durability. Due to these properties, scrapped rails are often used as a billet material in balls manufacturing for: balls for mills (rail head), flat bars (rail central part) and blades (rail foot) [1]. At present, balls with diameters $\varnothing 60$ and $\varnothing 80 \mathrm{~mm}$ are made from the rail head by means of die forging methods, characterized by considerable material losses (flash appearance) and relatively small efficiency. The increase of balls manufacturing efficiency is sought in the application of cross-wedge rolling methods during their production, which allow for forming of a few balls simultaneously at relatively small waste [24]. Better results can be obtained using continuous forming method, which is, by no means, developed by the Author helical-wedge rolling (HWR) [5-7].

This paper presents an innovative method of manufacturing balls for mills from a scrapped rail head, worked out at Lublin University of Technology, basing on the helical rolling process in helical wedges. At present, helical rolling processes are used for elongation of round bars, including bimetal ones [8-11]. In these processes from two up to four conical flat wedges, placed askew to the rolled part axis, are used. Yet, HWR method is successfully applied for rolling of balls formed from cylindrical billet (bar) [5, 7]. However, there are no solutions making possible application in the rolling process billet of different shape.

\section{DESCRIPTION OF THE BALLS HELICAL ROLLING FROM THE SCRAPPED RAIL HEAD}

The worked out process of the balls helical rolling from the scrapped rail head is characterized by a semi-finished part in a form of a head part cut from the scrapped rail placement in the guiding bush, which is located in the initial space of two working rolls and two guiding devices. Next, working rolls are put into rotary motion in the same direction and with the same velocity, the pusher is put into translational motion and it moves the semi-finished part into the working space. During rolling, conical parts of rolls catch the semi-finished part and put it into rotary motion in the direction opposite to rolls rotational 
direction and they displace it axially at the same time. As a result of rolls conical parts acting the semi-finished part cross section assumes the required circular shape. Later, in such formed material wedges are cut off, which forms balls in the way typical for the helical-wedge rolling. At the end of the rolling process bridges connecting balls are cut and the final products (balls) are obtained.

\section{NUMERICAL SIMULATION BASING ON FEM}

Verification of the rightness of the worked out balls manufacturing method was made by numerical simulation with the application of Simufact. Forming software. This software was fre-quently used by the author and other researchers for the analysis of cross and helical rolling pro-cesses [12-17] and the results from calculations were in good compatibility with the results of experimental research. It was assumed in calculations that the behavior of the formed material (steel of R200 type), in hot metal forming conditions, is described by the following equation:

$$
\begin{gathered}
\sigma_{p}=9898,75 \cdot \varphi^{0,111} \cdot \exp (-0,594 \cdot \varphi) \cdot \dot{\varphi}^{0,227} . \\
\cdot \exp (-0,00415 \cdot T)
\end{gathered}
$$

where: $\sigma_{p}$-yield stress, $\mathrm{MPa}$;

$\varphi$ - effective strain;

$\dot{\varphi}-$ strain rate, $\mathrm{s}^{-1}$;

$T$ - temperature, ${ }^{\circ} \mathrm{C}$.

In order to increase shape compactness billet in a form of the rail head (of length $250 \mathrm{~mm}$ ) underwent side pressing before rolling, realized according to the schema shown in Figure 1. In calculations assumed that:

- pressing will be realized in hexagonal impression, with edges rounded by radius $\mathrm{R} 7 \mathrm{~mm}$, inscribed in circle with diameter $70 \mathrm{~mm}$;

- billet temperature is $1150^{\circ} \mathrm{C}$, and dies temperature is equal $250^{\circ} \mathrm{C}$ and does not change during forging;

- friction factor at the material-tool contact area is equal to 0.5 ;

- heat exchange coefficient between tools and material equals $10 \mathrm{~kW} / \mathrm{m}^{2} \mathrm{~K}$;

- the upper die moves during forming with constant velocity $50 \mathrm{~mm} / \mathrm{s}$, which corresponds to application of hydraulic press in the side pressing.

According to Figure 1, the application of side pressing improved the billet shape in relations
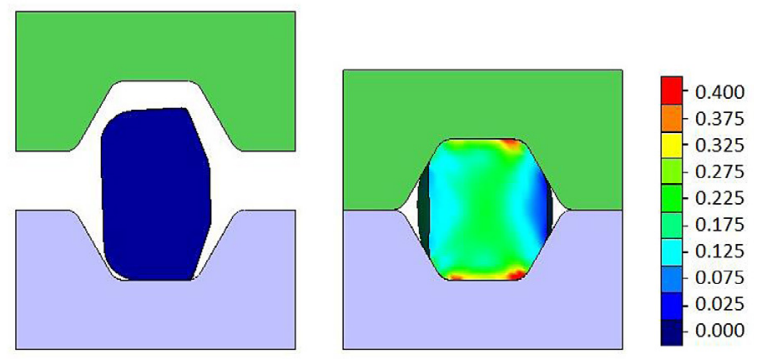

Fig. 1. The rail head upsetting in a hexagonal impression with the marked distribution of effective strain

to the next operation, which is helical rolling. Namely, billet places itself easily into the hole of diameter $70 \mathrm{~mm}$, which is made in the guiding bush. However, it is not important that billet after pressing has irregular shape at the length (Fig. 2). It is more compact (bulgy) in the middle part than at the edges, where it underwent elongation. At the same time, billet fulfilled four edges of the impression in every place, which guarantees its stable movement in the guiding sleeve. On the basis of calculations it was stated that the force required for the billet initial forming has a relatively small value - about 1.6 MN (Fig. 3). This means that this process can be realized in laboratory conditions at Lublin University of Technology.

The next Figure 4 presents geometrical model of the worked out process of helical rolling. This model consists of two identical conical rolls, two guiding devices (keeping billet in the space between rolls), bush implementing billet, the pusher and billet (pressed sideway rail head). In the rolling process simulation was assumed that the rolls rotated (in the same direction) with the same velocity $60 \mathrm{rot} / \mathrm{min}$ and that they were chamfered

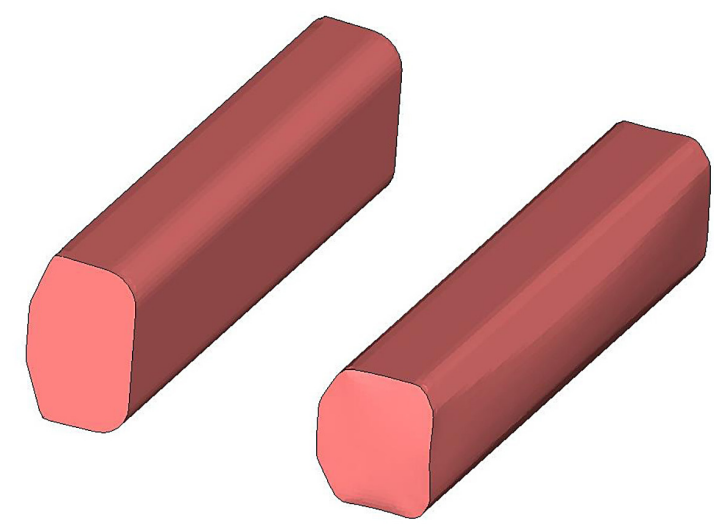

Fig. 2. Three-dimensional view of billet-head of the scrapped rail (on the left) and forging after side pressing process (on the right); it is visible that the forging in the central part is more bulgy than on the edges, where it underwent elongation 


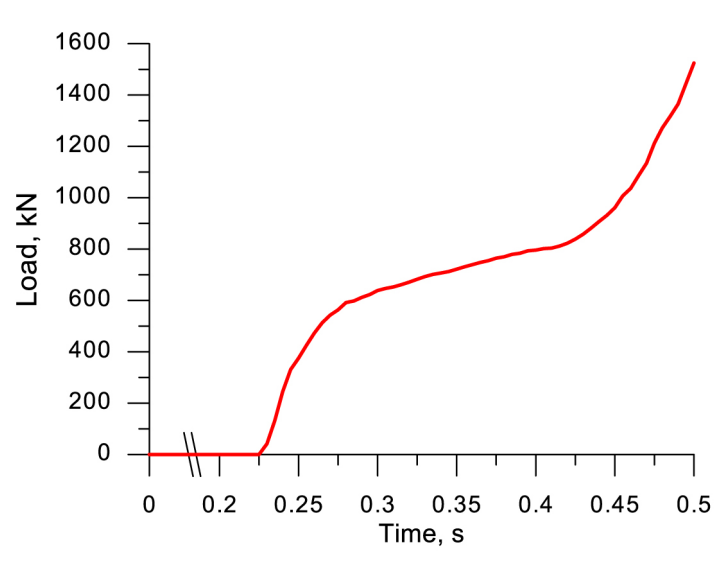

Fig. 3. Distribution of the forging force in the side pressing process of the scrapped rail head

in terms of the moving material axis. The pusher movement, described by axial velocity $10 \mathrm{~mm} / \mathrm{s}$ and necessary for the billet implementation between rolls, is limited only to the initial stage of the process. The forming time equal $8 \mathrm{~s}$ underwent modeling, during which rolls made 8 rotations. It was assumed that friction factor was equal to 1.0 for rolls and 0.4 for bushes and guides. Other parameters were assumed the same as in the side pressing process.

Figure 5 shows schematically the shape of a helical roll, which application should guarantee manufacturing from the scrapped rails heads balls of diameter $\varnothing 50 \mathrm{~mm}$. It consists of three parts. The first part has the shape of a truncated cone, which generating line is inclined to the roll axis at the angle $8^{\circ}$. This part of the tool is destined for billet sizing in such a way that in cross section it should reach the required circular shape (during rolling the roll is inclined to the billet axis at the angle $5^{\circ}$, which results in that the tool inclination angle in relation to the formed material decreases

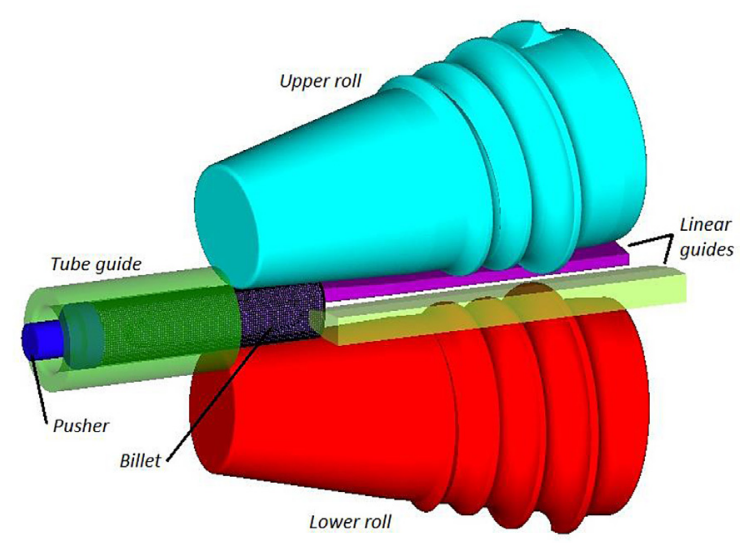

Fig. 4. Geometrical model of skew rolling process of balls directly from the scrapped rail head

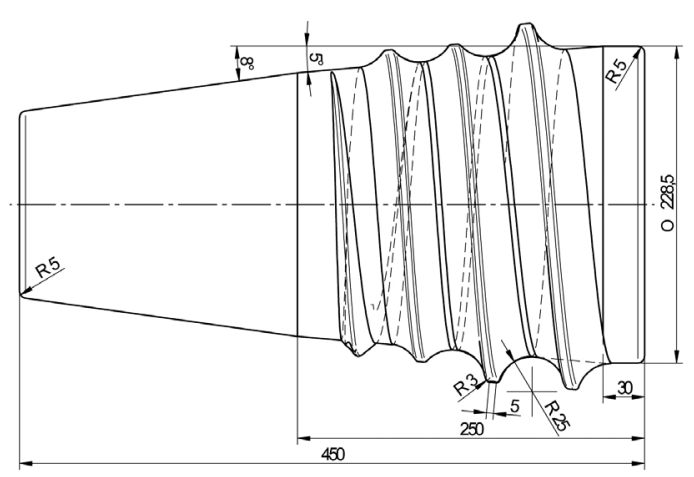

Fig. 5. The roll protecting helical rolling process of balls directly from the rail head

in the initial area up to $3^{\circ}$ ). The second part of the tool constitutes a truncated cone, with generating a line angle equal $5^{\circ}$, on which a flange for balls forming is wound helically. The flange helical line stroke is changeable (increasing) and its value is chosen from condition of constant volume of material closed between neighboring flanges, which is equal the volume of the formed ball. At the end of the flange a cutting knife should be mounted, used for separation of the formed ball (the knife was omitted on purpose as material separation would cause finishing numerical calculations). The last part of the tool has a cylindrical shape and allows for smooth leading out the formed balls from the forming zone.

In the result of the performed calculations, the rightness of the worked out rolling conception was confirmed, which course (in axial section) is given in Figure 6. It is visible that the initial cone placed at the beginning of rolls area

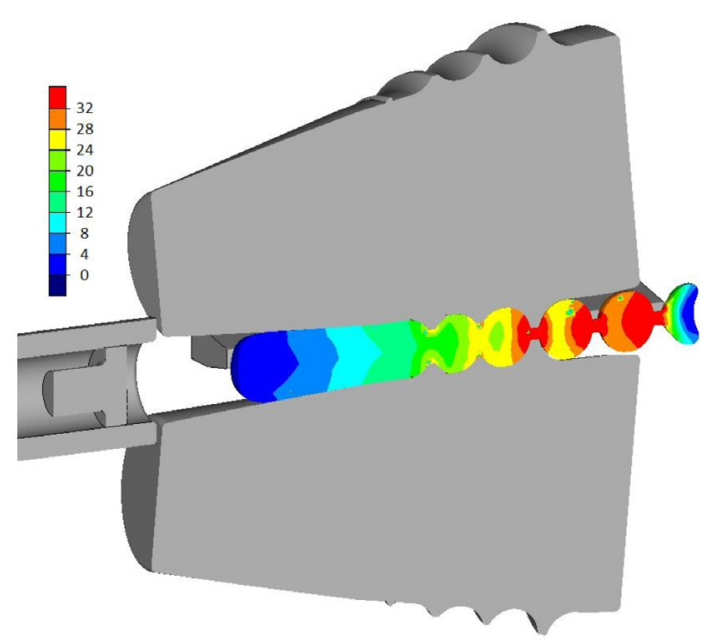

Fig. 6. The semi-finished product formed in a longitudinal section with marked distribution of effective strain 


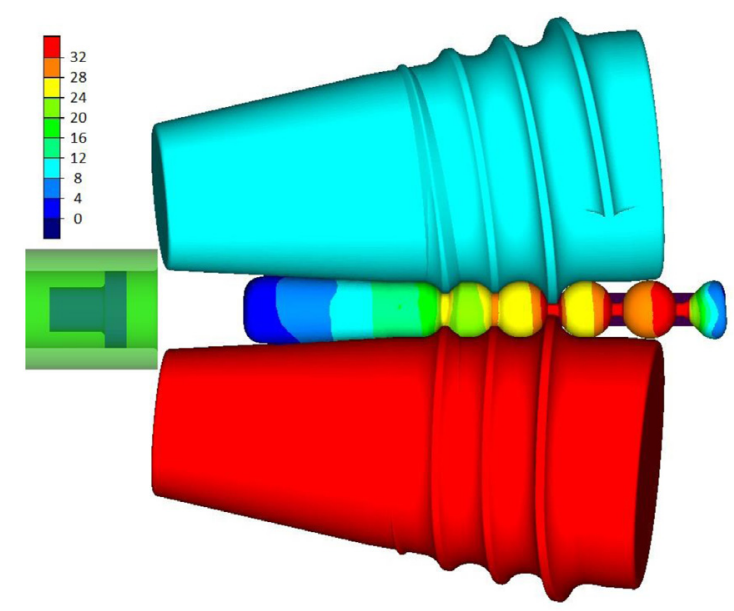

Fig. 7. Shape progression of the workpiece during skew rolling in helical rolls for time $\mathrm{t}=8 \mathrm{~s}$

acts well. It forms a cylindrical bar of the assumed diameter and gradually draws it between rolls. Helical flanges placed in the second part of the roll cut in a continuous way into the bar and form balls of $\varnothing 50 \mathrm{~mm}$, connected with bridges of small diameter. Products obtained by means of this type of rolling do not show shape faults (infilling and overlapping), although they were formed from billet of cross section different from circular.
Figures 6 and 7 present how an effective strain in the formed product changes. It is visible that strains assume considerably large values, which is a characteristic feature for cross and skew rolling. The presence of large values of effective strain should be explained by prevailing during forming material flow in the circumferential direction, caused by the friction force action.

The applied schema of the cylindrical bar manufacturing does not lead to a considerable decrease of the formed material temperature. According to Fig. 8 it remains within the scope proper for metal forming in hot conditions (above $950^{\circ} \mathrm{C}$ ) and allows for making the next operation - balls hardening. Obtaining such a favorable temperature distribution should be connected with generating large amounts of heat during rolling, in which plastic work and friction work are changed.

FEM application also allowed for determining force parameters of the analyzed helical rolling process. The next Figures 9 and 10 present distributions of radial force (rolls elbowing) and rolling moment respectively. A characteristic feature is that at the determined rolling stage (the last five roll's rotations) both force and moment assume oscillating character, resulting from cyclical flanges penetrating the formed material. Con-

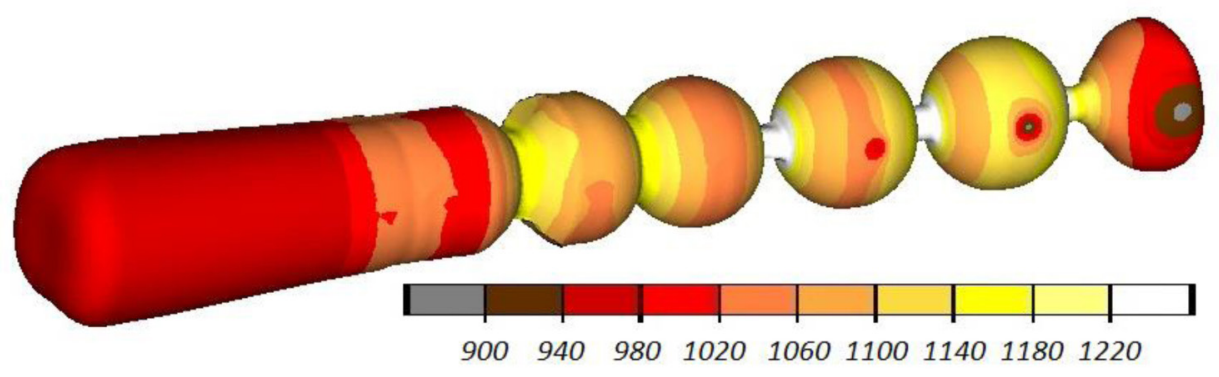

Fig. 8. Temperature distribution $\left(\right.$ in ${ }^{\circ} \mathrm{C}$ ) in the workpiece after making by rolls 8 rotations

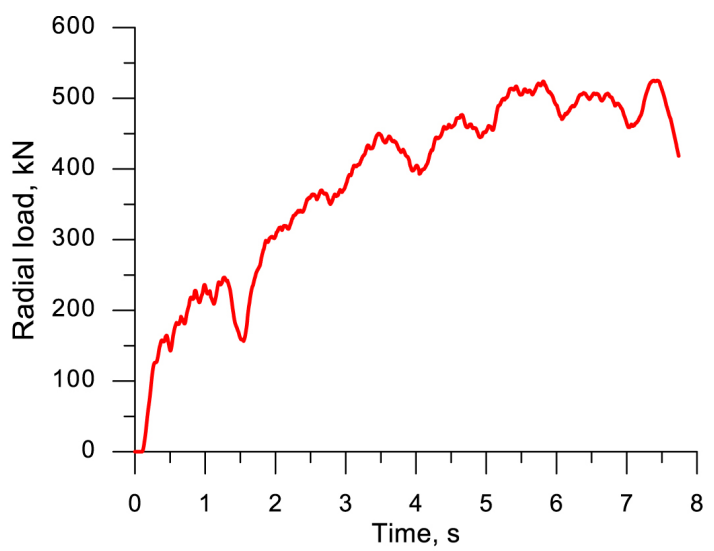

Fig. 9. Distribution of the radial force, acting on rolls in the helical rolling process of balls of $\varnothing 50 \mathrm{~mm}$ diameter

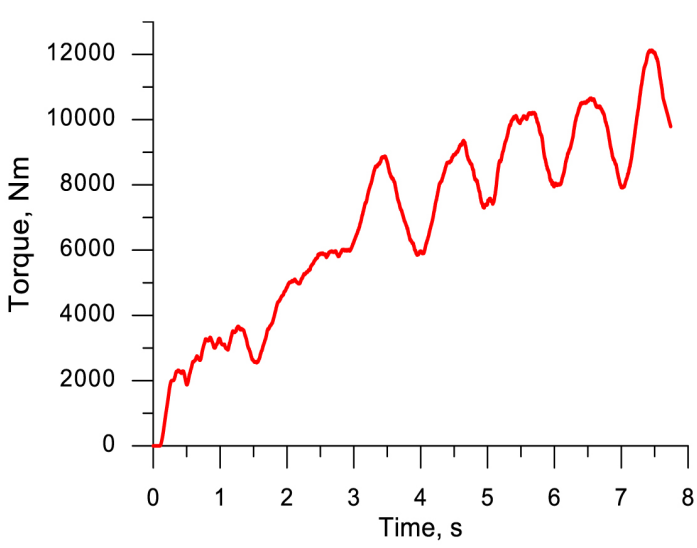

Fig. 10. Distribution of torque on the roll in the helical rolling pro cess of balls of $\varnothing 50 \mathrm{~mm}$ diameter 
cerning the maximal values of force (about 540 $\mathrm{kN}$ ) and moment (about $12100 \mathrm{Nm}$ ), it should be stated that they are considerably smaller than the values possible to apply in a laboratory skew rolling mill, being the equipment of the Lublin University of Technology. Therefore, this process can be verified in laboratory tests of rolling, with application of real material.

\section{CONCLUSIONS}

The following conclusions were drawn basing on the conducted numerical analysis:

- the worked out helical rolling method gives possibility of manufacturing balls from scrapped rails heads destined for mills in ball mills;

- heads of the scrapped rails before rolling should undergo side pressing in order to increase the density of cross section shape;

- temperature of balls manufactured by means of helical rolling allows for the application of further manufacturing operation-hardening;

- characteristic feature of force parameters of the worked out helical rolling process is their oscillating course, resulting from cyclical cutting of rolls flanges into material;

- maximal values of force and rolling moment noticed in simulations are smaller than those possible to obtain in hydraulic press and skew rolling mill at Lublin University of Technology;

- it is advisable to make helical rolling tests of balls from scrapped rails heads at Lublin University of Technology in laboratory conditions.

\section{Acknowledgements}

The work realized within the agreement $\mathrm{nr}$ INNOTECH-K3/IN3/12/ 226286/NCBR/14 concerning performing and finance of the project realized within the program "INNOTECH" in the subprogram IN-TECH.

\section{REFERENCES}

1. Pater Z., Tomczak J.: Walcowanie śrubowe kul do młynów kulowych. Wyd. Politechniki Lubelskiej, Lublin, 2012.

2. Pater Z., Gontarz A., Weroński W.: Cross-wedge rolling of balls. Steel Research International. "Special edition: Metal Forming 2008”, 1, 2008, 369-374.

3. Pater Z.: Multi-wedge cross rolling of balls. Jour- nal of Iron and Steel Research International, 20 (10), 2013, 46-50.

4. Pater Z.: New methods of steel ball rolling. International Journal of Materials \&Product Technology, 47 (1-4), 2013, 12-22.

5. Tomczak J., Pater Z., Bulzak T.: Designing of screw impressions in the helical rolling of balls. Archives of Civil and Mechanical Engineering, 14 (1), 2014, 104-113.

6. Pater Z.: Analysis of the helical-wedge rolling process for producing a workholding bolt. Metalurgija, 53 (4), 2014, 653-656.

7. Pater Z., Tomczak J., Bartnicki J., Lovell M. R., Menezes P. L.: Experimental and numerical analysis of helical-wedge rolling process for producing steel balls. International Journal of Machine Tools \& Manufacture, 67, 2013, 1-7.

8. Bogatov A.A., Panov E.I.: Effect of Stress-strain State during Helical Rolling on Metal and Alloy Structure and Ductility. Metallurgist, 57 (5-6), 2013, 434-441.

9. Tartakovskii B.I.: Reduction mills in helical rolling. Steel in Translation, 39 (7), 2009, 590-592.

10. Sawicki S., Szota P., Dyja H.: Analysis of the bimetallic bars rolling during a skew rolling. Archives of Materials Science and Engineering, 32 (1), 2008, 53-56.

11. Sawicki S., Szota P., Mróz S., Stefanik A., Dyja H.: Wpływ prędkości obrotowej na stan naprężeń i odkształceń prętów bimetalowych w procesie walcowania na trójwalcowej walcarce skośnej. Obróbka Plastyczna Metali, 20 (1), 2009, 65-75.

12. Pater Z., Tomczak J., Bulzak T.: Numerical analysis of the skew rolling process for main shafts, Metalurgija, 54 (4), 2015, 627-630.

13. Pater Z.: Analysis of the Helical-Wedge Rolling Process for Producing a Long Stepped Shaft. Key Engineering Materials, 622-623, 2014, 883-889.

14. Qiana D., Maoa H., Dengb J., Yue J.: Processing optimization for large spherical valve body based on FE simulation, Procedia Engineering, 81, 2014, 2481-2487.

15. Cao Q., Hua L., Quian D.: Finite element analysis of deformation characteristics in cold helical rolling of bearing steel-balls, Journal of Central South University, 22 (2), 2015, 1175-1183.

16. Qian D., Pan Y.: 3D coupled macro-microscopic finite element modelling and simulation for com $\neg$ bined blank-forging and rolling process of alloy steel large ring, Computational Materials Science, 70, 2013, 24-36.

17. Berti G.A., Quagliato L., Monti M.: Set-up of radial-axial ring-rolling process: Process worksheet and ring geometry expansion prediction, International Journal of Mechanical Sciences, 99, 2015, 58-71. 